\title{
HEALTH CARE-SEEKING BEHAVIOUR OF COASTAL COMMUNITIES IN BANYUWANGI, INDONESIA: RESULTS OF A CROSS-SECTIONAL SURVEY
}

\author{
Susy K. Sebayang, Erni Astutik, Desak Made Sintha Kurnia Dewi, Ayik Mirayanti \\ Mandagi, Septa Indra Puspikawati
}

\author{
Faculty of Public Health, Universitas Airlangga - Banyuwangi Campus, J1. Wijaya Kusuma \\ No 113 Banyuwangi, East Java Indonesia \\ Email: sksebayang@fkm.unair.ac.id
}

\begin{abstract}
Introduction: Improving health care-seeking behaviour of the coastal communities is a pathway to improving their health. This analysis aims to explore the health care-seeking behaviour of coastal communities in Banyuwangi District to recommend room for improvement for health promotion and health service improvement for these communities. Method: Data from a cross-sectional survey of metabolic syndrome and mental health conducted in coastal communities in Banyuwangi were used for analysis. Randomly selected participants from a list of members of the Family Welfare Development Group (Pembinaan Kesejahteraan Keluarga/PKK) were asked for an interview at corresponding village offices in Ketapang, Bangsring, Bulu Agung, Grajagan and Kampung Mandar village. Distribution of health care-seeking behaviors was analysed individually and where possible segregated by gender and age. Results: More than half of the coastal communities in Banyuwangi District went to health care services to seek health and 7 out of 10 turned to health care services to seek health for their family members. Women more than men turned to health care services when they or their family members fell ill. Private doctors rather than Puskesmas were more popular. Private midwives were the most popular service for antenatal care (ANC) and delivery. Although there was not a clear increase in health care service utilisation over time, we found that contraceptive utilisation increased with time. Conclusion: The utilisation of health care services in Banyuwangi needs to be further promoted especially for men's health.
\end{abstract}

Keywords: health care-seeking behaviour, health care services, maternal health care, coastal communities

\section{INTRODUCTION}

As an archipelagic country, Indonesia has a long coastline and abundant marine and coastal resources (Hutomo \& Moosa 2005). Under Joko Widodo's government, Indonesia is currently focusing its efforts on developing its marine and coastal resources to build an independent, advanced and strong maritime country (Kementerian Perencanaan Pembangunan Nasional/Badan Perencanaan Pembangunan Nasional 2014). In addition, the government of Indonesia also has a mission to create a high and advanced quality of life for Indonesians (Kementerian Perencanaan Pembangunan Nasional/Badan Perencanaan Pembangunan Nasional 2014). Consequently, development of human resources in the coastal communities is an obvious pathway to take. However, the health of the coastal communities, as one important factor for quality human resources, is yet to be optimally improved.

Understanding health care-seeking behaviour is an important factor in providing for the needs of community (Musoke et al. 2014). Coastal communities in Indonesia are usually poor and have low education (Cahaya 2015). These two factors alone may affect their health care-seeking behaviour in a way that will eventually affect their health. Basic Health Research 2013 reported that only $88.5 \%$ of farmers and fishermen access antenatal care service (ANC) and 71.2\% went for ANC at least 4 times. It was also reported that $25 \%$ of people from these groups of the population give birth without assistance from health professionals (Kementerian Kesehatan RI 2013a).

Banyuwangi, a district located in East Java, has ten coastal subdistricts and $176 \mathrm{~km}$ of coastline (Badan Pusat Statistik Kabupaten Banyuwangi 2015). Banyuwangi district government is rapidly developing its tourism industry throughout the region including in coastal areas (Pemerintah Kabupaten Banyuwangi 2011). Banyuwangi government also set improving health and access to healthcare as one of its development strategies (Pemerintah Kabupaten Banyuwangi 2011). Therefore, health care-seeking behaviour is expected to change either through specific targeting of health improvement or the growing economy of the district. However, studies on health care-seeking behaviour of Banyuwangi's coastal communities and the change over time is scarce. This study aims to 
explore health care-seeking behaviours of the coastal communities in Banyuwangi to discover room for improvement in health services and health promotion in this area.

\section{METHODS}

The analyses used data from a survey of metabolic syndrome and mental health conducted in coastal communities in Banyuwangi in September - November 2016. A permit for the survey was obtained from Banyuwangi's Badan Kesatuan Bangsa dan Politik and Banyuwangi District Health Office. Ethical clearance was approved by the Ethical Committee of the Faculty of Public Health of Universitas Airlangga in Surabaya, Indonesia no 521-KEPK.

The original cross-sectional survey was conducted on 100 women and 51 men randomly selected from members of the family welfare development groups (Pembinaan Kesejahteraan Keluarga/PKK) in five randomly selected villages.

The selected villages were Ketapang in Kalipuro Subdistrict, Bangsring in Wongsorejo Subdistrict, Bulu Agung in Silir Agung Subdistrict, Grajagan in Purwoharjo Subdistrict and Kampung Mandar in Banyuwangi Subdistrict. The respondents were requested to come to their corresponding village office for an interview and health checks. The interview was conducted one on one with trained data collectors after the consent process.

For the analysis of overall health careseeking behaviour, we included from the dataset men and women of productive age (aged 15-64 years old). For maternal and child health care-seeking behaviour we limited our analysis to women of reproductive age (15-45 years old). Distributions of health care-seeking behaviours were analysed individually and where possible were segregated by gender and age. Descriptive analysis was conducted using Stata 11.

\section{RESULTS}

There were 97 women $(66.4 \%)$ and 49 men $(33.6 \%)$ in the analysis of overall health care-seeking behaviour. Most respondents were 40-49 years old (43.2\%) and the mean age was $44.04 \pm 10.21$ ).

Table 2 shows that most respondents reported going to health care services $(55.2 \%)$ when they fell ill. Slightly more women $(58.3 \%)$ than men $(48.9 \%)$ preferred to go to health care services. Men preferred to purchase medicine over the counter when they were sick. For those who went to health care services, most respondents reported they went to private doctors $(48.1 \%)$, followed by Community Health Centres (Puskesmas) or Auxiliary Community Health Centres (Pustu) $(29.1 \%)$.

When their family members became sick, most respondents also reported taking their family members to health care services. The proportion of respondents who took their family members to health care services was greater than when they were sick $(70.4 \%$ vs. $55.2 \%$ ). More women reported taking their family members to health care services. The top three choices for health services for family members were private doctors $(40 \%)$, Puskesmas/Pustu (31\%) and private midwives (23\%). We did not find a clear increase in health care service utilisation with decreasing age.

Women were involved in all decisions regarding their health, including going to health services for a cure or health checks or for purchasing medicine or vitamins (Table 2). Most men reported that their spouse was not involved in the decisions regarding men's health. In fact, only $36,2 \%$ of men reported that their spouse alone or together with him made decisions to go to health services when he had fallen ill; $38.6 \%$ reported that their spouse was involved in the decisions to go to health service for disease prevention or health checks, and $40.8 \%$ reported women's involvement in purchasing medicine for their spouse.

Nearly $70 \%$ of women of reproductive age went to a private midwife for ANC for her youngest child. The utilisation of private midwives tended to reduce with time. Village level services such as Posyandu, Polindes or Poskesdes were accessed more by women aged 30-39 years old. For delivery, $67.2 \%$ of women chose maternity clinics or health professionals' private practices, followed by hospital birth $(23 \%)$. Although most women breastfed their children, only $48.4 \%$ of women exclusively breastfed their children. However, younger women exclusively breastfed their children (63.6\%) compared to older women (54.6\% for $30-39$ years old and $37.9 \%$ for 40 
45 years old), showing an increase in the practice over time (Table 3 ).

Seventy percent of women reported using contraception currently. There was an apparent increase in trends towards birth control use with time. Younger women used contraception more commonly compared to older women (Figure 1). Most women used injectables (48\%) followed by pills $(20 \%)$ and Intrauterine devices (IUDs) (17\%). There was an increasing trend towards the use of pills and implants as more younger women used pills and implants than older women (Figure 2).
We found a similar tendency when we limited our analysis to maternal health careseeking behaviour amongst women with children under five years old $(\mathrm{n}=27)$. In this subset of women, $51.8 \%$ went to private midwives for ANC, 51.9\% went to maternity clinics or private health professionals followed by $40.7 \%$ who went to hospitals for delivery, and $48.2 \%$ exclusively breastfed their children. More women currently used contraceptive methods in this subset of women (89\%), with birth control injectables and pills remaining the top two favourite contraceptive methods.

Table 1. Health care-seeking behaviour of male and female respondents aged 15-64 years old

\begin{tabular}{|c|c|c|c|c|c|c|}
\hline \multirow[t]{2}{*}{ Questions and Categories } & \multicolumn{2}{|c|}{ Women } & \multicolumn{2}{|c|}{ Men } & \multicolumn{2}{|c|}{ Total } \\
\hline & $\mathbf{n}$ & $\%$ & $\mathbf{n}$ & $\%$ & $\mathbf{N}$ & $\%$ \\
\hline \multicolumn{7}{|l|}{ What do you do when you are sick? } \\
\hline Nothing & 1 & 1.0 & 2 & 4.3 & 3 & 2.1 \\
\hline Buy medicine in shops & 25 & 26.0 & 16 & 34.0 & 41 & 28.7 \\
\hline $\begin{array}{l}\text { Buy medicine in pharmacies without } \\
\text { prescription }\end{array}$ & 4 & 4.2 & 3 & 6.4 & 7 & 4.9 \\
\hline Go to health care services & 56 & 58.3 & 23 & 48.9 & 79 & 55.2 \\
\hline Other & 10 & 10.4 & 3 & 6.4 & 13 & 9.09 \\
\hline \multicolumn{7}{|c|}{$\begin{array}{l}\text { If you go to health care services which health care } \\
\text { services do you go to? }\end{array}$} \\
\hline $\begin{array}{l}\text { Community Health Centre (Puskesma } \\
\text { Auxiliary Puskesmas }\end{array}$ & 17 & 30.4 & 6 & 26.1 & 23 & 29.1 \\
\hline Private midwife & 10 & 17.9 & 2 & 8.7 & 12 & 15.2 \\
\hline Private nurse & 3 & 5.4 & 2 & 8.7 & 5 & 6.3 \\
\hline Private doctor & 26 & 46.4 & 12 & 52.2 & 38 & 48.1 \\
\hline Private hospital & 0 & 0.0 & 1 & 4.4 & 1 & 1.3 \\
\hline \multicolumn{7}{|c|}{ What do you do if a member of your family is sick } \\
\hline Nothing & 1 & 1.1 & 0 & 0.0 & 1 & 0.7 \\
\hline $\begin{array}{l}\text { Buy medicine in shops } \\
\text { Buy medicine in pharmacies without }\end{array}$ & 17 & 17.9 & 12 & 25.5 & 29 & 20.4 \\
\hline 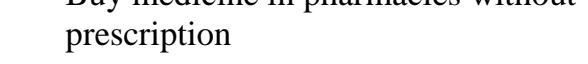 & 3 & 3.2 & 3 & 6.4 & 6 & 4.2 \\
\hline Go to health care services & 69 & 72.6 & 31 & 66.0 & 100 & 70.4 \\
\hline Other & 5 & 5.3 & 1 & 2.1 & 6 & 4.2 \\
\hline
\end{tabular}

If you take your family members to health services which health care services do you take them to?

Community Health Centre (Puskesmas) /

\begin{tabular}{lrrrrrr} 
Auxiliary Puskesmas & 21 & 30.4 & 10 & 32.3 & 31 & 31.0 \\
Private midwife & 17 & 24.6 & 6 & 19.4 & 23 & 23.0 \\
Private nurse & 1 & 1.5 & 3 & 9.7 & 4 & 4.0 \\
Private doctor & 30 & 43.5 & 10 & 32.3 & 40 & 40.0 \\
Private hospital & 0 & 0.0 & 2 & 6.5 & 2 & 2.0 \\
\hline
\end{tabular}


Health Care Seeking-Behavior of Coastal Communities (Susy K. Sebayang et. al.)

Table 2. Women's involvement in household decision-making

\begin{tabular}{|c|c|c|c|c|c|c|}
\hline \multirow[t]{2}{*}{ Type of Decisions } & \multicolumn{2}{|c|}{ Women } & \multicolumn{2}{|c|}{ Men } & \multicolumn{2}{|c|}{ Total } \\
\hline & $\mathrm{N}$ & $\%$ & $\mathrm{n}$ & $\%$ & $\mathrm{~N}$ & $\%$ \\
\hline \multicolumn{7}{|c|}{ To go to health services when sick } \\
\hline Women not involved & 21 & 22.3 & 30 & 63.8 & 51 & 36.2 \\
\hline Women involved & 73 & 77.7 & 17 & 36.2 & 90 & 63.8 \\
\hline \multicolumn{7}{|c|}{$\begin{array}{l}\text { To go to health services for disease } \\
\text { prevention or health checks }\end{array}$} \\
\hline Women not involved & 12 & 15.2 & 27 & 61.4 & 39 & 31.7 \\
\hline Women involved & 67 & 84.8 & 17 & 38.6 & 84 & 68.3 \\
\hline \multicolumn{7}{|c|}{$\begin{array}{l}\text { To purchase pharmaceutical } \\
\text { medicine, herbal medicine, or } \\
\text { vitamins }\end{array}$} \\
\hline Women not involved & 18 & 19.0 & 29 & 59.2 & 47 & 32.6 \\
\hline Women involved & 77 & 81.1 & 20 & 40.8 & 97 & 67.4 \\
\hline
\end{tabular}

Table 3. Maternal and child health care-seeking behaviour for the last pregnancy in women aged 1545 years old

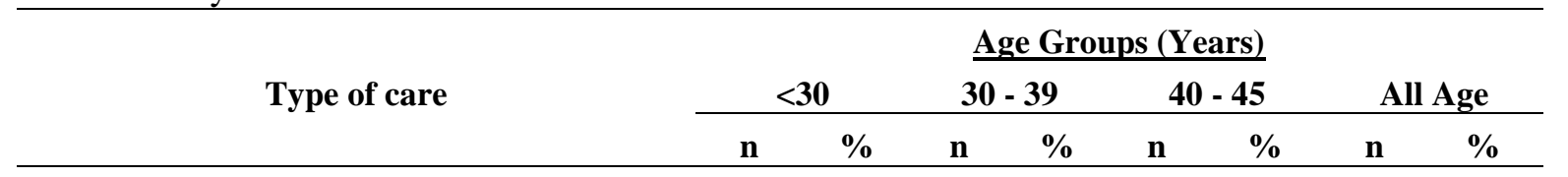

Place for antenatal care

Village level service (Posyandu, Polindes or Poskesdes)

District level service (Puskesmas atau

Pustu)

Hospital, clinics, private doctor or

OBGYN

Private midwife

$\begin{array}{rrrrrrrr}1 & 9.1 & 1 & 4.6 & 1 & 3.5 & 3 & 4.8 \\ 2 & 18.2 & 7 & 31.8 & 1 & 3.5 & 10 & 16.1 \\ 1 & 9.1 & 4 & 18.2 & 2 & 6.9 & 7 & 11.3 \\ 7 & 63.6 & 10 & 45.5 & 25 & 86.2 & 42 & 67.7\end{array}$

Place of birth

$\begin{array}{lrrrrrrrr}\text { Hospital } & 5 & 50.0 & 5 & 22.7 & 4 & 13.8 & 14 & 23.0 \\ \begin{array}{l}\text { Birth clinic/clinic/private health } \\ \text { professional }\end{array} & 5 & 50.0 & 15 & 68.2 & 21 & 72.4 & 41 & 67.2 \\ \text { Puskesmas or Pustu } & 0 & 0.0 & 2 & 9.1 & 0 & 0 & 2 & 3.3 \\ \text { Home or other place } & 0 & 0.0 & 0 & 0 & 4 & 13.8 & 4 & 6.6\end{array}$

Ever breastmilk

$\begin{array}{lrrrrrrrc}\text { No } & 1 & 9.1 & 1 & 4.6 & 1 & 3.5 & 3 & 4.8 \\ \text { Yes } & 10 & 90.9 & 21 & 95.5 & 28 & 96.6 & 59 & 95.2\end{array}$

Exclusive breastfeeding

\begin{tabular}{lllllllll} 
No & 4 & 36.4 & 10 & 45.5 & 18 & 62.1 & 32 & 51.6 \\
Yes & 7 & 63.6 & 12 & 54.6 & 11 & 37.9 & 30 & 48.4 \\
\hline
\end{tabular}




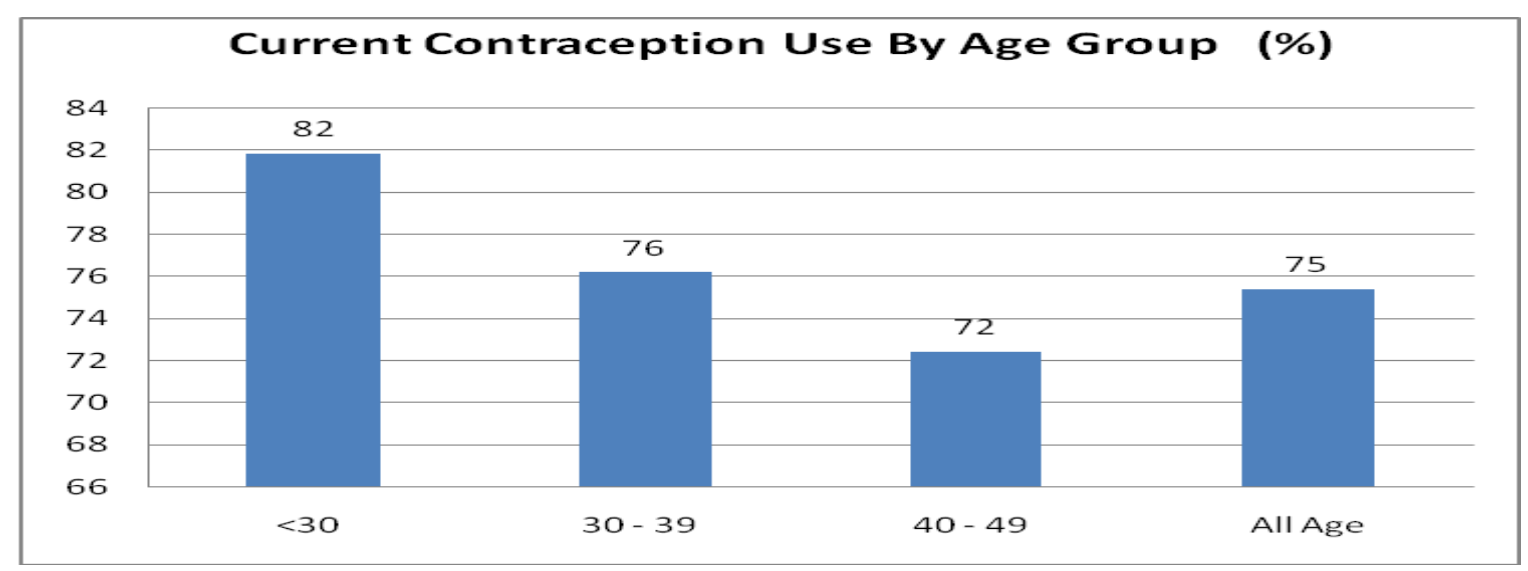

Figure 1. Current Contraception Use Among Women Aged 15-45 Years Old by Age Group

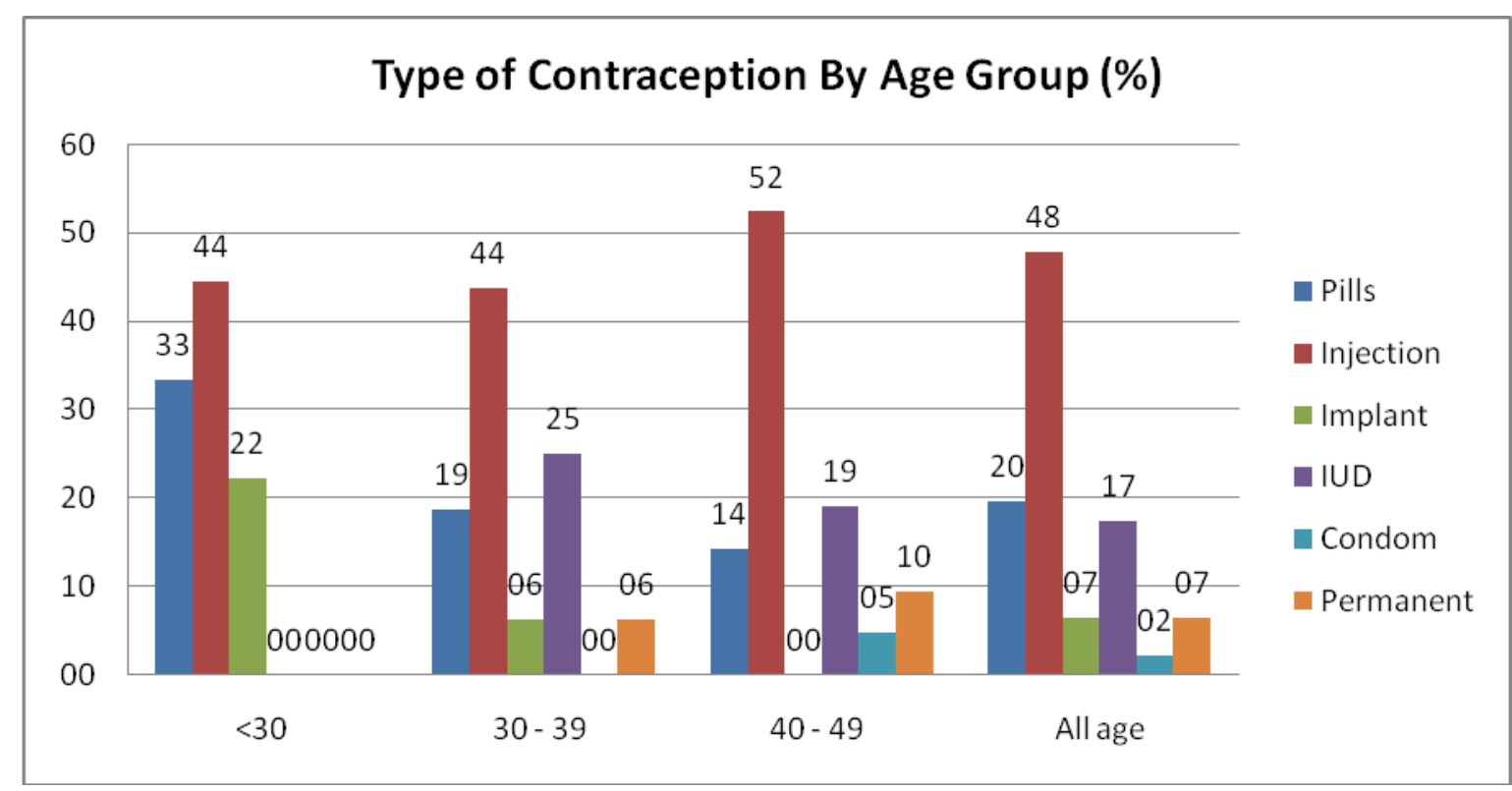

Figure 2. Type of Contraceptive Methods Used by Women Aged 15-45 Years Old by Age Group

\section{DISCUSSION}

Our study found that more than half of the coastal communities in Banyuwangi District went to health care services to seek health and 7 out of 10 turned to health care services to seek health for their family members. Women more than men turned to health care services when they or their family members fell ill. Interestingly, they chose to go to private doctors more than Puskesmas. In these communities women took part in household decision-making for their health and men reported that women were less involved in the decision-making for men's health. Private midwives were the most popular service for ANC and delivery.

We found that these coastal communities accessed health care services more than traditional coastal communities such as in South East Sulawesi or East Kalimantan where traditional healers remained the primary providers of health care (Martiyana and Handayani 2015; Nurrachmawati and Anggraeni 2010). More women than men in our study went to seek help from health care services. This fact is also reported for other countries especially for cases of sexually transmitted diseases (Cornell 2013). That men's health care seeking behaviour is lower than that of women for any disease in Indonesian coastal communities is an interesting finding. In fact, a study on gender inequalities in health care-seeking behaviour in Indonesia and globally are rarely conducted (Cornell 2013), and this finding contributes to the knowledge of gender differentials in health care-seeking behaviour. Our study found that most women in our study area $(67.2 \%)$ gave 
birth at maternity clinics or private health professional practices, followed by hospital births (23\%). Our findings are similar in trend to the results from Basic Health Research in 2013 in Banyuwangi. The 2013 survey reported that most mothers $(76.1 \%)$ in Banyuwangi went to maternity clinics or private health professionals to give birth, followed by hospital births $(10.7 \%)$ (Kementerian Kesehatan RI 2013b). Although similar in trend, compared to the general Banyuwangi population, there is a lower proportion of women who gave birth in maternity clinics, or private practices and more women gave birth in a hospital in our study population. Our estimate was slightly lower for women's involvement in decision-making on their health compared to an estimate for East Java from a national survey that found $82 \%$ of women in East Java were involved in decisionmaking for their health (Statistics Indonesia 2013). Current contraceptive use in our study area was $75 \%$ which was higher than the reported current contraceptive use for all Banyuwangi subdistricts (63\%) (Kementerian Kesehatan RI 2013b).

The fact that more women went to seek health care services than men may indicate that health care services were more popular for women as they provided more maternal and child care than specific men's health care. Lower access by men to health care services can partly be explained by less involvement of women in the decision-making for men's health. Although we did not find a clear increase in the proportion of health care service utilisation over time, there was an increase in contraception utilisation over time. The fact that private doctors were more popular than Puskesmas can be explained by the fact that we randomly selected respondents from PKK members who usually come from middle-upper socio-economic status.

Studies have shown that availability of health insurance improved formal health facility utilization (Fenny et al. 2015), especially among the low-income groups (Paek et al. 2016). However, despite the availability of national free delivery program (Jampersal) and national health insurance program, access of Puskesmas for birth in these communities has not increased with time. This, however, needs to be further studied as the number of women with children under five years old in this study, that can represent maternal health care-seeking behavior in the last five years, was limited. Although most women accessed institutionalized service for ANC and delivery, the quality of health care services received, however, may not be enough to impact exclusive breastfeeding. This supports the fact that although the trend of exclusive breastfeeding increased, the number was still low at $63.6 \%$ for women $<30$ years old.

The strength of this study was that we randomly selected respondents from five different subdistricts and as such we covered all the major and minor ethnic groups in the coastal areas including Javanese, maduranese, osing and other ethnic groups. Although the sample size was not balanced between men and women, we were able to present segregated analysis of health care-seeking behavior. Our samples were randomly selected from PKK members. Although PKK members usually represent the upper middle class of the communities, we were still able to find that access to health care service in this community was low (55.2\%). Another weakness of the study was that the number of PKK members who had under five-year-old children was limited and thus our estimates of maternal and child health care-seeking behavior must be interpreted with caution.

Our study suggests the need for promotions on the utilization of health care service especially Puskesmas in coastal communities of Banyuwangi. There is especially need to focus on improving men's access to health care. In Indonesia and many other developing countries, health care has been promoted more on providing health care for women and children as they are considered to be more vulnerable compared to men. Health promotion with a specific message for improving access to health care utilization among men is very scarce. Brotherhood system in which men become a member of the male group may also be utilized to create peer pressure towards health care service utilization (Grande et al. 2013). The programmatic implication above may be applicable not only to Banyuwangi's coastal communities but also to other coastal communities in Indonesia. However, studies for other coastal communities are needed to assess how culture affect health care seeking differently.

There need to be further studies on gender inequalities in health care for men. Further studies are also needed to assess the 
changes in health care-seeking behavior about the utilization of national health insurance scheme in coastal communities. As teen pregnancy in Banyuwangi is still frequent, this study should include factors affecting maternal health care-seeking behavior of adolescent mothers at the individual, interpersonal and family, community and social as well as organizational and health systems level (Shahabuddin et al. 2017).

Our findings also implied the need for promotion of exclusive breastfeeding in these coastal communities. In addition, there also needs to be more studies on the quality of available health care services in these coastal communities. There are 12,827 coastal villages in Indonesia (Badan Pusat Statistik 2015). Health care-seeking behavior in other coastal villages in Indonesia may differ from Banyuwangi. Therefore, more studies need to be done in other coastal villages to help design appropriate health promotion strategies for coastal communities.

\section{CONCLUSION}

Slightly half of the community members in the coasts of Banyuwangi accessed health care service for themselves and 7 out of 10 accessed it for their family members. Private midwives were the most popular service for ANC and delivery. The utilization of health care service needs to be more promoted in coastal communities, especially for men's health.

\section{REFERENCES}

Badan Pusat Statistik, 2015. Jumlah Desa/Kelurahan Menurut Provinsi dan Letak Geografi, 2003 - 2014.

Cahaya, A., 2015. Fishermen Community in the Coastal Area: A Note from Indonesian Poor Family. Procedia Economics and Finance, 26, pp.29-33. Available at: http://linkinghub.elsevier.com/retrieve/pii /S2212567115008011.

Cornell M, 2013. Gender inequality: Bad for men's health. South Afr J HIV Med, 14(1), pp.12-14.

Fenny, A.P. et al., 2015. Treatment-seeking Behaviour and Social Health Insurance in Africa: the Case of Ghana under the National Health Insurance Scheme. Global Journal of Health Science, 7(1).
Grande, S.W., Sherman, L. \& Shaw-Ridley, M., 2013. A Brotherhood Perspective. American Journal of Men's Health, 7(6), pp.494-503.

Hutomo, M. \& Moosa, M.K., 2005. Indonesian Marine and Coastal Biodiversity: Present Status. Indian Journal of Marine Sciences, 34(1), pp.88-97. Available at: http://nopr.niscair.res.in/handle/12345678 9/1546.

Kementerian Kesehatan RI, 2013a. Riset Kesehatan Dasar 2013 Dalam Angka,

Kementerian Kesehatan RI, 2013b. Riset Kesehatan Dasar Dalam AngkaRiskesdas 2013: Provinsi Jawa Timur,

Kementerian Perencanaan Pembangunan Nasional/Badan Perencanaan Pembangunan Nasional, 2014. Rancangan Awal Rencana Pembangunan Jangka Menengah Nasional 2015 - 2019: Buku I -Agenda Pembangunan Nasional, Jakarta: Kementerian Perencanaan Pembangunan Nasional/Badan Perencanaan Pembangunan Nasional.

Martiyana, C. \& Handayani, L., 2016. Health Seeking Behaviour of Non Communicable Disease in Sulaho Village, Lasusua Sub District, North Kolaka Regency. Buletin Penelitian Sistem Kesehatan, 18(4), pp.377-386.

Musoke, D. et al., 2014. Health seeking behaviour and challenges in utilising health facilities in Wakiso district, Uganda. African health sciences, 14(4), pp.1046-55. Available at: http://www.ncbi.nlm.nih.gov/pubmed/25 834516.

Nurrachmawati A and Anggraeni I., 2010. Tradisi Kepercayaan Masyarakat Pesisir Mengenai Kesehatan Ibu di Desa Tanjung Limau Muara Badak Kalimantan Timur Tahun 2008. Jurnal Kesehatan Reproduksi, 1(1), pp.42-50.

Paek, S.C., Meemon, N. \& Wan, T.T.H., 2016. Thailand's universal coverage scheme and its impact on health-seeking behavior. SpringerPlus, 5(1), p.1952.

Pemerintah Kabupaten Banyuwangi, 2011. Rencana Pembangunan Jangka Menengah Daerah Kabupaten Banyuwangi Tahun 2010 - 2015, Banyuwangi: Pemerintah Kabupaten Banyuwangi.

Shahabuddin, A. et al., 2017. Exploring Maternal Health Care-Seeking Behavior 
Health Care Seeking-Behavior of Coastal Communities (Susy K. Sebayang et. al.)

of Married Adolescent Girls in Bangladesh: A Social-Ecological Approach U. Simeoni, ed. PLOS ONE, 12(1), p.e0169109.

Statistics Indonesia, 2013. Survey Demografi dan Kesehatan Indonesia Indonesia Demographic and Health Survey. 